\title{
Developing the system of municipal property management of the city of Irkutsk: using the mechanisms of municipal-private partnership
}

\author{
Irina Yamshchikova ${ }^{1}$, and Elena Bobrova ${ }^{1, *}$ \\ ${ }^{1}$ Irkutsk National Research Technological University, 664074, Lermontova str., 83, Russia
}

\begin{abstract}
The authors have performed economic and statistical analysis of dynamics of income from the use and sale of municipal property in the city of Irkutsk in the structure of non-tax revenue of local budget, and identified key problems impeding effective management and disposal of municipal property in Irkutsk. They proposed perspective directions of solution of the identified issues, including expanding of sphere and practice of use of mechanisms of municipal-private partnerships in the management of municipal property. The major issues impeding implementation and development of mechanisms of municipal-private partnership on the concession terms on the territory of Irkutsk have been identified, and prospective directions of their development suggested. Necessity of work to be carried out by local bodies on development of methodological materials containing basic requirements and practical tools on preparation and implementation of projects of municipal-private partnership on the concession terms is justified in the paper, including a legal model, a technical model, and a financial and economic (financial) model. The authors proposed using indicators of socio-economic effectiveness of implementation in the framework of financial and economic model of concession projects.
\end{abstract}

\section{Introduction}

The terms "municipal property" and "municipal property management" have recently appeared in the theory and practice of the Russian economics. It happened in course of the reform of relationship and forms of property in 1990s. In contemporary economic conditions, management of the municipal property objects, and implementation of measures focused on increasing effectiveness of such management are the important tasks of local self-governing bodies in any municipality.

Municipal property management is executed in the interests of population of the municipality and in the context of strategic priorities of its development. It should be focused on the achievement of the following purposes:

- Creation of the optimal structure of municipal property;

- Ensuring economic basis of local self-governing;

\footnotetext{
* Corresponding author: e.u.bobrova@yandex.ru
} 
- Creation of holistic and effective system of management of the municipal property objects;

- Increased revenues for the local budget;

- Increased competitiveness and investment attraction of the municipality providing attraction of investments into economics of the municipality, creation of additional workplaces, and development of the municipal infrastructure.

Effective municipal property management provides for high and sustainably increasing quality of life of the population in the municipality through maximum satisfaction of its interests and demands, and promotes creation of favorable social environment.

\section{Materials and methods}

Performance reports data of the city of Irkutsk budget for 2010 - 2016 and information on performance of the city budget as on 01.01 .2018 (for 2017) displayed on the official website of the Irkutsk municipality have become the basis for economic and statistical analysis of the dynamics of income from the use and sales of municipal property in the city of Irkutsk. The data collection has been done with the use of reporting and statistical methods.

Theoretical studies of the patterns of have been performed with the use of mathematical statistics. According to the data of the official website of the Irkutsk municipality and reports on the city budget performance, diagrams have been developed and approximated that reflected trends in change of revenues in the local budget. Polynomial approximation has been used for the analysis of data, which represented a set of alternately increasing and decreasing values.

\section{Results}

Ensuring effective use of municipal property and lands in the city of Irkutsk aimed at solving local issues is an important strategic purpose of the municipal policy in the city in the sphere of municipal property management. The achievement of this purpose is envisaged in the framework of implementation of the municipal program "Increasing quality of municipal property management in the city of Irkutsk, and land plots on the territory of the city of Irkutsk for 2013-2020" (the Program) [2].

In current circumstances, sustainability of economics of Irkutsk and opportunities for its stable development are determined by the level of development of the land and property relations. According to the Program, effective municipal property management includes the following:

- Provision for preservation, functioning and development of the municipal property objects;

- Utilization of all municipal property objects in the interests of the municipality and population of the city;

- Replenishment of the local budget revenues with the purpose of the most complete implementation of plans of development of municipal education and powers to address local issues.

Strict compliance of structure of municipal property to powers of local authorities and provision of effectiveness of the municipal property use with the optimal level of expenses for management are the basic principles of municipal property management. In this connection, a number of issues impeding effective management of the municipal property objects in the city of Irkutsk should be outlined:

- The presence in the municipal property of the city of Irkutsk the property that does not intend for solution of issues of local value, or not demanded by local administration bodies; 
- Insufficient level of provision of object of municipal property with actual technical documentation and title documents;

- The need to carry out works of identification, certification and subsequent registration of ownerless real estate (usually the objects on engineering infrastructure) to the municipal ownership;

- A threat of loss and destruction of the objects of municipal property due to a high degree of their depletion;

- Lack of demand for the municipal property objects on the real estate market due to their poor technical state, low level of consumer qualities, remote location from the central areas and highways of the city, and lack of technical opportunities to connect them to the engineering networks;

- Insufficient level of formation of the fund of municipal lands;

- Absence of timely implemented geodetic surveys and expertise of the actual use of lands by individuals and legal entities, and, as a consequence, insufficient evidentiary basis for the protection of property interests of the municipality in case of adjudication of disputes;

- Incomplete works on formation of land plots under municipal property, and a lack of monitoring system for the formed and allocated land plots;

For the solution of these issues, the Program envisaged implementation of the complex of measures in the framework of the three subprograms with different targets:

- «Improvement of management and the order of municipal property in the city of Irkutsk»;

- «Improvement of the efficiency of land use in Irkutsk»;

- «Capital repairs and reconstruction of the non-residential fund of municipal property».

As mentioned above, replenishment of the local budget revenues is one of the indicators of quality of the existing system of municipal property management. Let us consider the dynamics of income of the use and sales of municipal property in the city of Irkutsk in the structure of non-tax revenue of the local budget in 2010-2017 (Table 1).

Table 1 Income of the use and sales of municipal property in the city of Irkutsk in the structure of non-tax revenue of the local budget in 2010-2017.

\begin{tabular}{|c|c|c|c|}
\hline Year & $\begin{array}{l}\text { Amounts of income, thousand } \\
\text { RUR / } \\
\text { Share in the total amount of non- } \\
\text { tax revenues, } \%\end{array}$ & $\begin{array}{l}\text { Growth rate to the } \\
\text { basic year, } \%\end{array}$ & $\begin{array}{l}\text { Growth rate to the } \\
\text { previous year, \% }\end{array}$ \\
\hline \multicolumn{4}{|c|}{ 1. Non-tax revenues, including: } \\
\hline \multirow{2}{*}{2010} & 1587070,6 & \multirow{2}{*}{$100.0 \%$} & \multirow{2}{*}{-} \\
\hline & $100 \%$ & & \\
\hline \multirow{2}{*}{2011} & 1699859,5 & \multirow{2}{*}{$\begin{array}{l}107.1 \% \\
(7.1 \%)\end{array}$} & \multirow{2}{*}{$\begin{array}{l}107.1 \% \\
(7.1 \%)\end{array}$} \\
\hline & $100 \%$ & & \\
\hline \multirow{2}{*}{2012} & 1495773,2 & \multirow{2}{*}{$\begin{array}{l}94.2 \% \\
(-5.8 \%)\end{array}$} & \multirow{2}{*}{$\begin{array}{c}88.0 \% \\
(-12.0 \%)\end{array}$} \\
\hline & $100 \%$ & & \\
\hline \multirow{2}{*}{2013} & 1644776,2 & \multirow{2}{*}{$\begin{array}{l}103.6 \% \\
(3.6 \%)\end{array}$} & \multirow{2}{*}{$\begin{array}{l}110.0 \% \\
(10.0 \%)\end{array}$} \\
\hline & $100 \%$ & & \\
\hline \multirow{2}{*}{2014} & 1847677,1 & \multirow{2}{*}{$\begin{array}{l}116.4 \% \\
(16.4 \%)\end{array}$} & \multirow{2}{*}{$\begin{array}{l}112.3 \% \\
(12.3 \%)\end{array}$} \\
\hline & $100 \%$ & & \\
\hline \multirow{2}{*}{2015} & 1442705,8 & \multirow{2}{*}{$\begin{array}{l}90.9 \% \\
(-9.1 \%)\end{array}$} & \multirow{2}{*}{$\begin{array}{c}78.1 \% \\
(-21.9 \%)\end{array}$} \\
\hline & $100 \%$ & & \\
\hline \multirow{2}{*}{2016} & 1335540,5 & \multirow{2}{*}{$\begin{array}{c}84.2 \% \\
(-15.8 \%)\end{array}$} & \multirow{2}{*}{$\begin{array}{l}92.6 \% \\
(-7.4 \%)\end{array}$} \\
\hline & $100 \%$ & & \\
\hline \multirow{2}{*}{2017} & 1178158,0 & \multirow{2}{*}{$\begin{array}{c}74.2 \% \\
(-25.8 \%)\end{array}$} & \multirow{2}{*}{$\begin{array}{c}88.2 \% \\
(-11.8 \%)\end{array}$} \\
\hline & $100 \%$ & & \\
\hline
\end{tabular}




\begin{tabular}{|c|c|c|c|}
\hline \multicolumn{4}{|c|}{ 1.1. Income of use of municipal property } \\
\hline \multirow{2}{*}{2010} & 980916,5 & \multirow{2}{*}{$100 \%$} & \multirow{2}{*}{-} \\
\hline & $61.8 \%$ & & \\
\hline \multirow{2}{*}{2011} & 970747,8 & \multirow{2}{*}{$\begin{array}{c}99.0 \% \\
(-1.0 \%)\end{array}$} & \multirow{2}{*}{$\begin{array}{c}99.0 \% \\
(-1.0 \%)\end{array}$} \\
\hline & 57.1 & & \\
\hline \multirow{2}{*}{2012} & 842228,6 & \multirow{2}{*}{$\begin{array}{c}85.9 \% \\
(-14.1 \%)\end{array}$} & \multirow{2}{*}{$\begin{array}{l}86.8 \% \\
(-3.2 \%)\end{array}$} \\
\hline & $56.3 \%$ & & \\
\hline \multirow{2}{*}{2013} & 1041968,5 & \multirow{2}{*}{$\begin{array}{l}106.2 \% \\
(6.2 \%)\end{array}$} & \multirow{2}{*}{$\begin{array}{l}123.7 \% \\
(23.7 \%)\end{array}$} \\
\hline & $63.4 \%$ & & \\
\hline \multirow{2}{*}{2014} & 1037960,0 & \multirow{2}{*}{$\begin{array}{l}105.8 \% \\
(5.8 \%)\end{array}$} & \multirow{2}{*}{$\begin{array}{c}99.6 \% \\
(-0.4 \%) \\
\end{array}$} \\
\hline & $56.2 \%$ & & \\
\hline \multirow{2}{*}{2015} & 887938,0 & \multirow{2}{*}{$\begin{array}{c}90.5 \% \\
(-9.5 \%) \\
\end{array}$} & \multirow{2}{*}{$\begin{array}{c}85.5 \% \\
(-14.5 \%) \\
\end{array}$} \\
\hline & $61.5 \%$ & & \\
\hline \multirow{2}{*}{2016} & 852299,0 & \multirow{2}{*}{$\begin{array}{c}86.9 \% \\
(-13.1 \%)\end{array}$} & \multirow{2}{*}{$\begin{array}{c}96.0 \% \\
(-4.0 \%) \\
\end{array}$} \\
\hline & $63.8 \%$ & & \\
\hline \multirow{2}{*}{2017} & 739090,1 & \multirow{2}{*}{$\begin{array}{c}72.7 \% \\
(-27.3 \%) \\
\end{array}$} & \multirow{2}{*}{$\begin{array}{c}83.7 \% \\
(-16.3 \%) \\
\end{array}$} \\
\hline & $60.5 \%$ & & \\
\hline \multicolumn{4}{|c|}{ 1.2. Income of sale of tangible and intangible assets } \\
\hline \multirow{2}{*}{2010} & 345718,3 & \multirow{2}{*}{$100.0 \%$} & \multirow[b]{2}{*}{-} \\
\hline & $21.8 \%$ & & \\
\hline \multirow{2}{*}{2011} & 463093,2 & $134.0 \%$ & $134.0 \%$ \\
\hline & $27.2 \%$ & $(34.0 \%)$ & $(34.0 \%)$ \\
\hline & 404836,8 & $117.1 \%$ & $87.4 \%$ \\
\hline 2012 & $27.1 \%$ & $(17.1 \%)$ & $(-12.6 \%)$ \\
\hline & 341242,6 & $98.7 \%$ & $84.3 \%$ \\
\hline 2013 & $20.7 \%$ & $(-1.3 \%)$ & $(-15.7 \%)$ \\
\hline 2014 & 455042,3 & $131.6 \%$ & $133.3 \%$ \\
\hline 2014 & $24.6 \%$ & $(31.6 \%)$ & $(33.3 \%)$ \\
\hline 2015 & 285321,0 & $82.5 \%$ & $62.7 \%$ \\
\hline 2015 & $19.8 \%$ & $(-17.5 \%)$ & $(-37.3 \%)$ \\
\hline 2016 & 188216,0 & $54.4 \%$ & $66.0 \%$ \\
\hline 2010 & $14.1 \%$ & $(-55.6 \%)$ & $(-44.0 \%)$ \\
\hline 2017 & 183467,0 & $53.1 \%$ & $97.5 \%$ \\
\hline 2017 & $15.6 \%$ & $(-56.9 \%)$ & $(-2.5 \%)$ \\
\hline
\end{tabular}

The Table is composed on the data of the city of Irkutsk budget performance for 2010-2016 and information on the budget performance on 01.01.2018 (information from the official website of the municipality of Irkutsk).

* 2010 has been taken as a basic year.

According to the information about the city of Irkutsk budget performance on 01.01.2018 (for the year 2017), displayed at the official website of the Irkutsk municipality, actual income of non-tax revenues in 2017 amounted to 1178158.0 thousand RUB, which is below the level of 2010 on 408912.6 thousand RUB (25.8\%).

The basic amount of non-tax revenues (more than 56\%) is stably consists of that of the use of municipal property. The share of income of sale of tangible and intangible assets in the structure of non-tax revenue during the analyzed period varied from $27.2 \%$ (in 2011) to $14.1 \%$ (in 2016).

According to the data of the statistical table, the approximated diagrams reflecting trends of changes of replenishment to the local budget have been developed (Figure 1).

As a result of the analyses, we have to point out the decreasing trend of the non-tax income in the revenues of local budget in 2015-2017. In 2017, the amount on non-tax income decreased on 669519.1 thousand RUB, as compared with 2014 in absolute figures, or by $36.2 \%$ in relative terms. It is connected, in particular, with the decreased level of revenues 
from the use of municipal property, and revenues from the sales of tangible and intangible assets that continued in 2015-2017.

For the analysis of data, that is the set of alternately increasing and decreasing values, polynomial approximation has been used, the parameters of equations of statistical dependence of the considered indicators have been determined, and trend lines constructed, on the basis of which further decrease in the level of income from the use and sale of municipal property in the city of Irkutsk has been predicted.

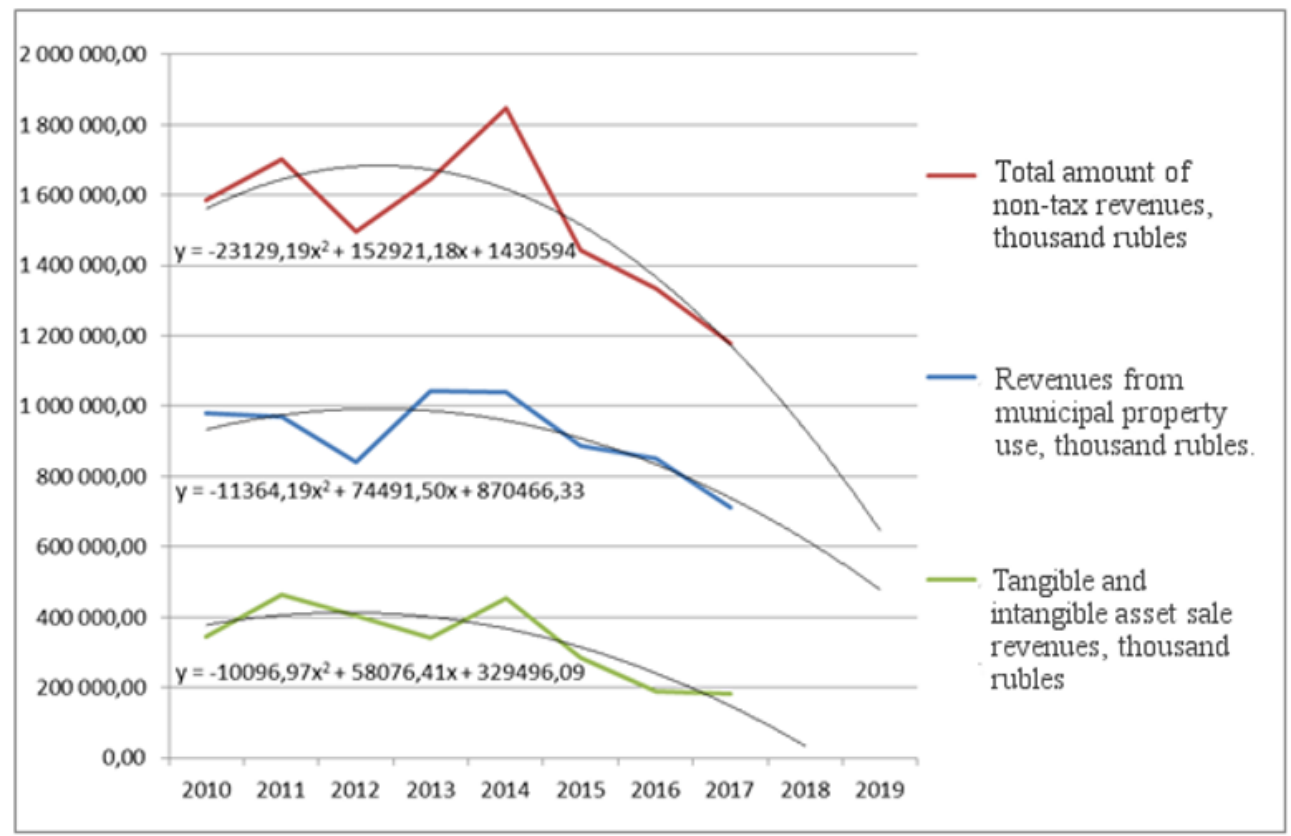

Fig. 1 Dynamics of incomes of the use and sales of municipal property of the city of Irkutsk in the structure of non-tax revenues of the local budget in 2010-2017.

Lack of demand for the municipal property objects on the real estate market and difficulties with their involvement in the economic turn-over is seen as one of the reasons for this situation. In $2014-2017$, there was a stable trend to decreasing of quantity and total area of the municipal property objects, in respect of which lease agreements were concluded. Auctions for the sale of the right to conclude a lease were recognized invalid due to low economic activity of the business entities and lack of applications. Low consumer qualities, remote location from the central areas and highways of the city impeded their effective use by the lease agreements.

In addition to that, the decreased level of income of the use of municipal property is impacted by the growing rent arrears on the lease agreements concluded for the nonresidential municipal fund objects, and termination of existing contracts for the use of municipal property.

Privatization of the municipal property objects cannot be referred as the most effective method of the municipal property management, since it leads to the decreased incomes to the municipal budget in the long-term prospective being, as a rule, a short-term source of income. Considering the stated above, the activity of local self-governing bodies of the city of Irkutsk in the sphere of municipal property management, it is necessary to concentrate on the following most effective directions:

- Improving consumer qualities of the municipal property objects in the city of Irkutsk;

- Ensuring preservation of municipal properties; 
- Proper registration of ownership and timely inventory of the municipal real estates and plots of land;

- Optimization of the process of exhibition of the objects of the municipal non-residential fund of the city of Irkutsk for the actions on sale of the right to conclude lease agreements;

- Intensification of work on debt collection for the objects of the municipal non-residential fund of the city of Irkutsk under lease;

- Expanding the sphere and practice of use of the mechanisms of public-private partnership in municipal property management.

\section{Discussion}

Municipal-private partnership is one of the most effective tools for development of public infrastructure based on long-term interaction of the municipality and business and sharing risks between the public and private partners. The analysis of the Russian and foreign experience indicates that the attraction of private capital to financing and management of municipal property based on the concession agreements is one of the most widely used methods of economic and organizational provision for the processes of development and effective use of municipal property [11-15].

The administration of the city of Irkutsk is carrying out work on attraction of private investments into the municipal economics by concluding concession agreements related to the municipal property objects. By this date, four concession agreements have been concluded and are being implemented, and one more is at the preparatory stage for signing and implementation.

Along with the provisions of federal and regional legislation, the activity of municipal bodies in the city of Irkutsk in the framework of preparation and implementation of projects of municipal-private partnership on the terms of concession for the municipal property objects in the city is regulated by the Order of the Irkutsk municipal administration № 031 06-256/7 signed 28.03.2017. This regulatory act defines the following [3]:

1. Basic provisions of the activity of workforces authorized by the Mayor of the city of Irkutsk to accept decisions on possibility to conclude concession agreements;

2. The order of acceptance of decisions on possibility (impossibility) to conclude concession agreement on the basis of complex analysis of information by the workforces.

However, the Order has not determined the subsequent procedure for concluding the concession agreements: according to this regulatory document, it is implemented in accordance with the Federal law "On concession agreements". Due to the lack of detailed methodology of preparation of concessional projects and signing concessional agreements elaborated at the municipal level, unification of legal, financial and management mechanisms in this sphere, expanding practice of the use of concessional mechanisms on the territory of the municipal entity is seen as difficult. Development and implementation of each of the concession agreements requires substantial labor and time resources, since activity of local self-government bodies in this sphere is not duly regulated.

Taking into account formulated above, we can outline the major issues impeding implementation and development of mechanisms of municipal-private partnership on the terms of concession agreements on the territory of the city of Irkutsk:

- Imperfection of legal framework for implementation of the concession projects;

- Lack of methodological developments and materials defining basic practical tools for preparation, signing and implementation of concession agreements on the territory of municipality;

- Lengthy character of decision-making by local self-administration bodies on possibility (impossibility) to conclude concessional agreements; 
- Shortage of effective instruments of attraction of potential investors for funding projects of municipal-private partnership;

- Insufficient level of control by the local self-administration bodies for the compliance by concessionaires with the terms of concession agreements.

The authors have suggested prospective directions of solution of the mentioned above issues:

1. Acceptance of additional regulation acts by the bodies of local self-governing that clarify or supplement the provisions of federal and regional legislation;

2. Provision of openness and transparency of information confirming real demand of the city in relevant objects of public infrastructure, also by the methods of annual authorization by the municipality of a list of potential objects, for which signing of concessional agreements is planned;

3. Functioning of the effective system of monitoring on the different stages of the projects implementation to be executed by the local self-governing bodies in order to ensure compliance by the concessionaire with terms of the concession agreement;

4. Organization of training of personnel of the governmental authorities and bodies of local self-government for improving practice of preparation of concessional agreements.

In addition to that, it is needed to do some work on elaboration of methodology documents containing basic requirements and practical tools on preparation and implementation of projects of municipal-private partnership on the terms of concession in order to simplify the procedure of development of the concession projects and signing of concession agreements. It is also necessary to include the requirements on composition and order of preparation of information about key components of a concessional project into the content of such a methodology, including [5]: legal model, technical model, and financial and economic (financial) model of a concession project.

The authors suggest performing evaluation of the project effectiveness at different stages of the project implementation in order to increase quality of the projects and effectiveness of budgetary costs into financial economic model of the concession projects. Along with traditional indicators of net present value (NPV), and internal rate of return (IRR), determining interest of a private investor to participate in implementation of a project $[7,16]$, as well as indicators of budget effectiveness [4], it is necessary to introduce an indicator, reflecting socio-economic effect from the implementation of a project.

As one of the purposes of implementation of concession agreements, along with provision for the effective use of municipal property, is a satisfaction of demands of population of the municipal entity through the provision of goods, works, services of high quality, we have suggested to use the indicator of the economic factor model, calculated by the method of L.M. Chistov [6-8], as an indicator of socio-economic effectiveness:

$$
E=\frac{\Delta P}{\sum C}
$$

$E$ - is socio-economic effectiveness of implementation of the concession project;

$\Delta P$ - increase in volume of production of socially needed goods, works, services in the cost units, conditioned by the measures on creation, reconstruction (modernization) of the object of the concessional agreement, as compared with the period, preceding the start of the implementation of the project;

$\Sigma \mathrm{C}$-expenses (costs) performed on implementation of actions for creation, reconstruction (modernization) of the object of the concessional agreement.

The parameter $\Sigma C$ reflects the extensive factor of the model as a number of resources used for the implementation of the project in value units invested by private partners 
(investors) to the implementation of the project $\left(\mathrm{I}_{\mathrm{p}}\right)$, and the amount of the budget investments $\left(\mathrm{I}_{\mathrm{b}}\right)$.

$$
\sum \mathrm{C}=\mathrm{I}_{\mathrm{p}}+\mathrm{I}_{\mathrm{b}}
$$

The proposed indicator fully takes into account the extensive and intensive factors of the concession project implementation, which reflect attraction of needed resources to the project, and also the socio-economic effect received in case of their effective use.

\section{Conclusion}

The qualitative study of the concession project, before it starts, embraces the following: identification and detailed analysis of risks; balanced distribution of risks between the parties fixed in the agreement; compliance of the project with the priorities of socio-economic development of the municipality; compliance of the terms of the agreement with the norms of legislation; maximum details of the agreement; availability of a clear-cut technical, legal and financial concepts of the project; guaranteed currency flows in the framework of the project; attractiveness of indicators of financial effectiveness for a private investor; tangible budgetary and socio-economic impact of the project.

Development of the methodological guidelines, unifying activities on preparation and implementation of the concession projects in legal, technical and financial standpoints, will intensify the process of decision-making by the local self-government bodies, increase effectiveness of attraction of private investments into development of the municipal property objects, and contribute to the increasing level of accessibility and quality of the provided public services.

\section{References}

1. Government of Russia, On concession agreements: Federal Law No. 115-FZ of July 21, 2005 (ConsultantPlus, Moscow, 2017)

2. City Administration of Irkutsk, On the approval of the municipal program "Improvement of the quality of municipal property management in the city of Irkutsk and land plots on the territory of the city of Irkutsk for 2013-2020" (ConsultantPlus, Moscow, 2018)

3. City Administration of Irkutsk, On approval of the procedure for concluding concession agreements with respect to municipal property in the city of Irkutsk (ConsultantPlus, Moscow, 2018)

4. V. V. Maksimov, Public-private partnership in transport infrastructure: evaluation criteria for concession tenders (Alpina Publishers, Moscow, 2010)

5. Yugra Development Fund, Methodical recommendations on the preparation and implementation of investment projects by concluding concession agreements (Yugra, 2017)

6. Kh. Z. Khalimbekov, A. G. Mamedov, Bulletin of the Dagestan State Technical University. Technical science, 18, 157-164 (2010)

7. S. S. Chernov, M. V. Filchenkova, Business. Education. Right. Bulletin of the Volgograd Business Institute, 3(32), 109-114 (2015)

8. L. M. Chistov, Society. Environment. Development, 2, 9-13 (2010) 
9. L. M. Chistov, Innovative as an optimization approach in the theory of management of socio-economic systems (Asterion, St. Petersburg, 2008)

10. D. V. Khodos, L. V. Stepanova, Russian Entrepreneurship, 11, 10-15 (2012)

11. I. V. Yamshchikova, E. Yu. Bobrova, Fundamental Research, 8(P2), 470-475 (2017)

12. J. Delmon, Public-private partnership projects in infrastructure: an essential guide for policy makers (Cambridge University Press, Cambridge, 2011)

13. E. Engel, R. D. Fischer, A. Galetovic, The economics of public-private partnerships: a basicgGuide (Cambridge University Press, Cambridge, 2014)

14. S. B. Friedman, Successful public-private partnerships: from principles to practices (Urban Land Institute, 2016)

15. World Bank and PPIAF, Public-private partnerships: reference guide (Washington, DC, 2012)

16. G. Damdinsuren, I. V. Yamschikova, E. Yu. Bobrova, Proceedings of Universities. Investment. Construction. Real Estate, 3(22), 11-18 (2017) 